\title{
SPECIAL WASTE VALORIZATION AND RENEWABLE ENERGY GENERATION UNDER A CIRCULAR ECONOMY: WHICH PRIORITIES?
}

\author{
ELENA CRISTINA RADA \\ Department of Theoretical and Applied Sciences, University of Insubria, Italy
}

\begin{abstract}
The European Union regulation for emissions from waste incinerators had a significant evolution in the last 20 years. That allowed reaching a clear improvement in the environmental performances of the plants, synchronized with specific requests of compliance of the more and more stringent limits set at regulatory level. Today the main questions for the sector in Europe seem mostly related to the role of waste to energy plants in a scenario of circular economy and to the role of those plants in the generation of energy only in part renewable. It seems that the topic of the local environmental and health impact has become out to date in European Union. In spite of that, a big question remains on the suitability of the present regulation for the future of the sector, including co-incineration by the use of Secondary Recovered Fuel from waste as substitute of coal in cement works. The present article analyzes an aspect that should be a priority higher than the concept of circular economy and energy generation. Indeed, a question remains on the criticalities that could be present in the European Union for under-estimation of the role of heavy metals, in spite of the evolution of the regulation. If we look at the experience of the University of Trento (where the Author worked in various research projects since 2003) the last decade has been characterized by recurrent warnings from that University about the excessive simplification of the regulation in case of heavy metals. As an example, in case of waste incineration, a set of heavy metals are managed by summing their concentrations to be compared as sum to the regulation limit: no valorization of the specific knowledge on toxicity is made. In order to point out the consequences of this simplification, a few case-studies demonstrating a potential criticality on the role of $\mathrm{Cr}^{\mathrm{VI}}$ are discussed. A control methodology integrating the present one is discussed in this article, to propose a solution suitable to avoid under-estimations of human exposure to heavy metals from incineration and co-incineration. This approach is particularly important when special waste is combusted as the composition of the input can present heavy metals concentrations higher than municipal solid waste.
\end{abstract}

Keywords: $\mathrm{Cr}^{V I}$, emissions, heavy metals, incineration, waste.

\section{INTRODUCTION}

The European Union (EU) regulation for emissions into the atmosphere from waste incinerators had a significant evolution in the last two decades. That allowed reaching a demonstrated improvement in the environmental performances of the plants, synchronized with specific progressive requests of compliance of limits set at regulatory level.

A significant case concerns $\mathrm{PCDD} / \mathrm{Fs}$ emissions from the incinerator sector. The introduction of more stringent limits in the late 1990s allowed a decrease of three orders of magnitude of the emissions approved in Italy thanks to the introduction of the limit of 0.1 $n g_{\text {TEQ }} / \mathrm{Nm}^{3}$ at the stack. The emission inventories confirmed a similar trend in EU. The same results (three orders of magnitude lower) did not characterize the sector of heavy metal emissions. The potential consequences are discussed in this article.

Nowadays, at local level, a few authorizations introduce the concept of guaranteed limits, more stringent than the authorized ones. In some cases, the difference between the regulation limits and the guaranteed ones is relevant. A case where this aspect can be seen extensively is the one of the incinerators of Bozen, Italy [1]. Here, differences are shown in Table 1. 
Table 1: Comparison between regulation limits and guaranteed limits of pollutants emitted from the Bozen plant, receiving municipal and special waste [2].

\begin{tabular}{|c|c|c|c|c|c|c|}
\hline & & \multicolumn{2}{|c|}{ Regulation } & \multicolumn{2}{c|}{ Guaranteed } & Reduction \\
\hline Pollutants & Units & Aver. & Period & Aver. & Period & \\
\hline Dust & $\mathrm{mg} / \mathrm{Nm}^{3}$ & 10 & $24 \mathrm{~h}$ & 1.5 & $24 \mathrm{~h}$ & $85 \%$ \\
\hline $\mathrm{HCl}$ & $\mathrm{mg} / \mathrm{Nm}^{3}$ & 10 & $24 \mathrm{~h}$ & 2 & $24 \mathrm{~h}$ & $80 \%$ \\
\hline $\mathrm{HF}$ & $\mathrm{mg} / \mathrm{Nm}^{3}$ & 1 & $24 \mathrm{~h}$ & 0.25 & $24 \mathrm{~h}$ & $75 \%$ \\
\hline $\mathrm{SO}_{2}$ & $\mathrm{mg} / \mathrm{Nm}^{3}$ & 50 & $24 \mathrm{~h}$ & 10 & $24 \mathrm{~h}$ & $80 \%$ \\
\hline $\mathrm{NO}_{\mathrm{x}}$ & $\mathrm{mg} / \mathrm{Nm}^{3}$ & 200 & $24 \mathrm{~h}$ & 40 & $24 \mathrm{~h}$ & $80 \%$ \\
\hline $\mathrm{NH}_{3}$ & $\mathrm{mg} / \mathrm{Nm}^{3}$ & 30 & $24 \mathrm{~h}$ & 10 & $24 \mathrm{~h}$ & $67 \%$ \\
\hline $\mathrm{Cd}+\mathrm{Tl}$ & $\mathrm{mg} / \mathrm{Nm}^{3}$ & 0.05 & $8 \mathrm{~h}$ & 0.025 & $8 \mathrm{~h}$ & $50 \%$ \\
\hline $\mathrm{Hg}$ & $\mathrm{mg} / \mathrm{Nm}^{3}$ & 0.05 & $8 \mathrm{~h}$ & 0.025 & $8 \mathrm{~h}$ & $50 \%$ \\
\hline $\mathrm{Heavy} \mathrm{metals}$ & $\mathrm{mg} / \mathrm{Nm}^{3}$ & 0.5 & $1 \mathrm{~h}$ & 0.25 & $1 \mathrm{~h}$ & $50 \%$ \\
\hline $\mathrm{PCDD} / \mathrm{F}$ & $\mathrm{ng}$ & $8 \mathrm{~h}$ & 0.025 & $8 \mathrm{~h}$ & $75 \%$ \\
\hline
\end{tabular}

Possibly, these guaranteed limits are the most stringent in EU for the sector of incineration. What must be pointed out is that Table 1 is that the case of heavy metals is the less involved in the emission reduction targets. Some important consequences of that are discussed below in this article.

Today the main questions for the sector seem mostly related to the role of waste to energy plants in a scenario of circular economy and to the role of those plants in the generation of energy only in part renewable [3]-[5]. Indeed, key documents of waste to energy and circular economy [6] do not refer specifically to the issue of local impact on environment and health. More in details, in 2015, the European Commission proposed specific recommendations on the waste legislations in force, linked with Circular Economy (CE) [7]. The aim was "to stimulate Europe's transition towards a circular economy which will boost global competitiveness, foster sustainable economic growth and generate new jobs" [7]. The EU action program proposed measures involving the whole cycle: "from production and consumption to waste management and the market for secondary raw materials" [7]. The kind of specific key targets for all the member states were the following [7]:

- To get a recycling common target by 2030 for Municipal Solid Waste (MSW) and packaging waste;

- To reduce landfilling of MSW by 2030;

- To prohibit landfilling of waste selectively collected;

- To rationalize definitions, methods and standards for recycling rates all over EU;

- To have concrete forms to support the close-loop of the material re-use option;

- To stimulate EU towards a sustainable market place by specific actions.

Small modifications were introduced afterwards, without modifying the overall vision given by the previous document. 
The above objectives relate to Municipal Solid Waste because European Union has considered that Circular Economy introduction in that field may also be driving for Special Waste (SW).

If we consider $\mathrm{CE}$ a priority in the EU waste management, the mentioned package of documents underlines the importance of reuse and recycling before energy recovery: the target is to close the loop of product lifecycles by an increase and an optimization of and reuse. This target is seen also in terms of favorable global balances for both the environment and the economy.

In the field of emissions from waste to energy plants, the discussion on BREFs (BAT Reference Report) is still active [8]. However, the approach is seen in terms of "conventional" emission improvements and not in terms of emission reduction targets. Indeed the control strategy at the stack does not change, in spite of the potential criticalities underlined below in this article.

The concept of partial renewable source for waste is intensively discussed in Italy every time a waste to energy plant is proposed. Recent criteria have been introduced in the sector allowing a choice between a detailed analysis of the biomass-like content of the waste and a flat approach: when the percentage of biodegradable matter in the waste fed to a plant is not known, that fraction can be assumed equal to $51 \%$. That can be done under specific conditions described in the paragraph 6 of Annex 2 of Ministerial Decree of July 6th, 2012, modified by Law no. 221/2015 art. 24 [9].

In the same period, in Italy, no new decision concerned a different approach related to incineration emission management for new emission targets (thus for new health risk targets).

The health impact from waste incinerators seems a topic more interesting in the Chinese context [10]. If we look at the recent production of articles in the Scopus data base, most of the recent works on this topic are authored in China. It seems, in EU, that the reached level of knowledge on heath and incineration and the methodology of control are considered adequate in the scientific domains.

In spite of the reduced interest on the local impact on health in EU, a big question remains on the suitability of the regulation in force for the future of the sector, including coincineration by the use of Secondary Recovered Fuel from waste as substitute of coal in cement works. Indeed an issue remains on the criticalities that could be present in the EU for under-estimation of the role of heavy metals, in spite of the past evolution of the regulation on emissions into the atmosphere. The present article focuses on it.

\section{CRITICALITIES OF HEAVY METALS EMISSION MANAGEMENT}

If we look at the experience of the University of Trento, where the Author worked in various research projects since 2003, the last decade has been characterized by recurrent reporting to local Authorities (e.g. Environmental Protection Agencies) about the excessive simplification of the regulation in case of heavy metals. As an example, in case of waste incineration, heavy metals are generally managed by summing their concentrations to be compared as sum to the regulation limit: no valorization of the specific knowledge on toxicity is made, apart from $\mathrm{Hg}$, considered alone. This concept will be analyzed in details in the following case studies. The direct consequence of this simplification is the lack of valorization of the detailed knowledge on the health effects of heavy metals, thanks to the progress in toxicology resumed below.

Differently from conventional macro-contaminants ( $\mathrm{Na}_{2}, \mathrm{SO}_{2}, \mathrm{CO}$ and some VOCs), for other pollutants the pathways of indirect exposure cause not negligible impacts (even dominants for a few compounds). This is the case of the toxic and persistent atmospheric pollutants, which include heavy metals, PCDD/Fs, PCBs and PAHs. Their characteristics of 
persistence and cumulability in the environment require a more articulated approach to calculate the risk for health associated to the human exposure. From the methodologic point of view, indeed, the study of their impact on health must be based on the concept of multiple pathways responsible of effects on the individuals exposed.

Pollutants, after emitted into the atmosphere, can penetrate into the human body directly (through inhalation) or can reach the soil by deposition. Here three pathways can give indirect exposure:

- Accidental ingestion of soil contaminated by the atmospheric depositions of pollutants;

- Dermal contact with contaminated soil;

- Ingestion of food contaminated by the pollutant's depositions to soil, leaves, fruits.

For many toxic and persistent atmospheric pollutants, e.g. PCDD/F, PCB and heavy metals, food chain is for humans an important way of risk, when not the main one. As consequence, among the pollutants of concern for the simulations of dispersion into the atmosphere, thus interesting for the health risk assessment, there are many carcinogenic pollutants. The International Agency for Research on Cancer, IARC, classified a number of compounds on the base of the outcomes of epidemiologic studies and experiments on animals, on the reliability and replicability of results [11]. In particular, IARC subdivides the carcinogenic compounds in four groups:

- Group 1: Carcinogenic to humans

- Group 2A: Probably carcinogenic to humans

- Group 2B: Possibly carcinogenic to humans

- Group 3: Unclassifiable as to carcinogenicity in humans

- Group 4: Probably not carcinogenic to humans

Table 2 reports the compounds typically used for the assessment of the health risk in case of incinerators and their IARC group. In order to simplify, in the present article only the carcinogenic risk is considered as it is sufficient to demonstrate the potential underestimation of the effects of heavy metals with the regulation in force.

Data on toxicity of each compound are available in form of Cancer Slope Factor (SF) for the carcinogenic substances. SF, expressed in $\left(\mathrm{mg} \mathrm{kg}_{\mathrm{bw}}{ }^{-1} \text { giorno- }{ }^{-1}\right)^{-1}$ where "bw" means body

Table 2: Classification from IARC for the carcinogenic compounds subject of the health risk assessment [11].

\begin{tabular}{|c|c|}
\hline Compound & Group IARC \\
\hline Arsenic & 1 \\
\hline Cadmium & 1 \\
\hline Chromium VI & 1 \\
\hline Mercury & 3 and $2 B^{\text {a }}$ \\
\hline Nickel & 1 \\
\hline PAHs & from 1 to 3 \\
\hline PCDD/Fs & 1 \\
\hline PCB dioxin-like & 1 \\
\hline
\end{tabular}


Table 3: Toxicologic characteristics of the considered pollutants.

\begin{tabular}{|c|c|c|}
\hline & $\begin{array}{c}\mathrm{SF}_{\text {inhal }} \\
{\left[\left(\mathrm{mg} \mathrm{kg}_{\mathrm{bw}^{-1}} \mathrm{~d}^{-1}\right)^{-1}\right]}\end{array}$ & $\begin{array}{c}\mathrm{SF}_{\text {oral }} \\
{\left[\left(\mathrm{mg} \mathrm{kg}_{\left.\left.\mathrm{bw}^{-1} \mathrm{~d}^{-1}\right)^{-1}\right]}\right.\right.}\end{array}$ \\
\hline Cadmium & $6.30 \mathrm{E}+00$ & - \\
\hline Tallium & - & - \\
\hline Arsenic & $1.50 \mathrm{E}+00$ & $1.50 \mathrm{E}+00$ \\
\hline Chromium III & - & - \\
\hline Chromium VI & $2.94 \mathrm{E}+02$ & - \\
\hline Nickel & $9.10 \mathrm{E}-01$ & $9.10 \mathrm{E}-01$ \\
\hline PCDD/F & $1.33 \mathrm{E}+05$ & $1.33 \mathrm{E}+05$ \\
\hline PAH $\left.{ }^{*}\right)$ & $4.20 \mathrm{E}+00$ & $7.30 \mathrm{E}+00$ \\
\hline PCB dl & $1.33 \mathrm{E}+04$ & $1.33 \mathrm{E}+04$ \\
\hline${ }^{*}$ SFs of the most toxic PAHs are reported.
\end{tabular}

weight is defined as the incremental cancer risk associated with a unit dose of a carcinogen. It is the slope of the curve representing the relationship between dose and cancer risk. Depending on the exposure pathway, inhalation or ingestion, we distinguish between $\mathrm{SF}_{\text {inhal }}$ and $\mathrm{SF}_{\text {oral }}$. Table 3 reports the toxicologic parameters available for the considered pollutants.

Rows for Tallium and Chromium III are reported even if they are blank, in order to take into account what discussed below.

From Table 3 we can remark that:

- Heavy metals show SFs in a range of two orders of magnitude

- In spite of that, the regulation in force sums heavy metal concentrations with no regard to their specific toxicity; as examples:

- In the regulation for incineration emissions at the stack, $\mathrm{Cd}+\mathrm{Tl}$ are summed even if only one has a SF

- Arsenic, Chromium and Nickel are summed with other six heavy metals even if only three have a SF

- The approach adopted for PCDD/Fs and PCBs, based on an equivalent toxicity, is not used in the sector of heavy metals

Possibly one reason of this simplified approach comes from the fact that in the past the organic micropollutants like PCDD/Fs drove the value of the total risk from an incinerator. As demonstrated in the following case studies related to the $\mathrm{Cr}^{\mathrm{VI}}$ issue, this cannot be longer accepted without an update of the criteria control as:

- The significant reduction of operating values in the emissions of PCDD/Fs changed the role of dominant pollutant; indeed in some cases heavy metals emerge driving the total risk value

- The approach in force in terms of limits for heavy metals based on a raw sum of concentration values of nine of them, allows critical cases when, for instance, $\mathrm{Cr}^{\mathrm{VI}}$ is a characteristic and not negligible pollutant in the emissions. 


\section{THE CHROMIUM ISSUE}

In order to point out the consequences of the simplification in the management of the issue of heavy metals emission, a few case studies demonstrating a potential criticality on the role of $\mathrm{Cr}^{\mathrm{VI}}$ are discussed. A control methodology integrating the present one is discussed too, to set a solution suitable to avoid under-estimations of human exposure. This approach is particularly important when special waste is combusted as the composition of the input can present heavy metals concentrations higher than RMSW (residual MSW, i.e. the one remaining after selective collection).

\subsection{RMSW and special waste incinerator's case study}

Supposing to consider a limit value of $\mathrm{Cd}$ at the stack as $50 \mu \mathrm{g} / \mathrm{Nm}^{3}$, it is clear that also for $\mathrm{Cr}^{\mathrm{VI}}$, carcinogenic, the emission at the stack must be coherent with that request. Taking into account the different $\mathrm{SF}$ of $\mathrm{Cr}^{\mathrm{VI}}$, along the pathway adopted to authorize the emissions of an Italian plant, it was proposed to introduce a maximum value of $\mathrm{Cr}^{\mathrm{VI}}$ to be guaranteed at the stack as $1 \mu \mathrm{g} / \mathrm{Nm}^{3}$ calculated on yearly basis (being a carcinogenic compound, its relevance is on a long period of exposure) [12].

Considering the novelty of the approach, a proposal of criteria for measuring it on yearly basis was left to the plant proposer.

As a consequence, the list of guaranteed values, integrating or partially substituting the regulation in force in that period, resulted as Table 4. This Table is valid for solutions of

Table 4: Concentration values to guarantee at the stack as integration or partial substitution of the regulation in force (values at $11 \% \mathrm{O}_{2}$, dry off-gas). The parameters that do not change from the regulation are not reported.

\begin{tabular}{|c|c|}
\hline Parameter & Values to be guaranteed \\
\hline Dust (daily average) & $2 \mathrm{mg} / \mathrm{Nm}^{3}$ \\
\hline TOC (daily average) & $5 \mathrm{mg} / \mathrm{Nm}^{3}$ \\
\hline $\mathrm{HCl}$ (daily average) & $2 \mathrm{mg} / \mathrm{Nm}^{3}$ \\
\hline HF (daily average) & $0.5 \mathrm{mg} / \mathrm{Nm}^{3}$ \\
\hline $\mathrm{NO}_{\mathrm{x}}$ (daily average) & $40 \mathrm{mg} / \mathrm{Nm}^{3}$ \\
\hline $\mathrm{NO}_{\mathrm{x}}$ (hourly average) & $200 \mathrm{mg} / \mathrm{Nm}^{3}$ \\
\hline $\mathrm{SO}_{2}$ (daily average) & $25 \mathrm{mg} / \mathrm{Nm}^{3}$ \\
\hline $\mathrm{NH}_{3}$ (daily average) & $5 \mathrm{mg} / \mathrm{Nm}^{3}$ \\
\hline $\mathrm{Cd}+\mathrm{Tl}$ (hourly average) & $0.01 \mathrm{mg} / \mathrm{Nm}^{3}$ \\
\hline $\mathrm{Hg}$ (hourly average) & $0.02 \mathrm{mg} / \mathrm{Nm}^{3}$ \\
\hline $\begin{array}{c}\mathrm{Sb}+\mathrm{As}+\mathrm{Pb}+\mathrm{Cr}+\mathrm{Co}+\mathrm{Cu}+\mathrm{Mn}+\mathrm{Ni}+\mathrm{V} \\
\text { (hourly average) }\end{array}$ & $0.2 \mathrm{mg} / \mathrm{Nm}^{3}$ \\
\hline PCDD/F (yearly average) & $0.03 \mathrm{ng}_{\mathrm{TEQ}} / \mathrm{Nm}^{3}$ \\
\hline BaP (yearly average) & $0.1 \mu \mathrm{g} / \mathrm{Nm}^{3}$ \\
\hline $\mathrm{Cr}^{\mathrm{VI}}$ (yearly average) & $1 \mu \mathrm{g} / \mathrm{Nm}^{3}$ \\
\hline Other parameters & $\begin{array}{c}\text { The eight hour sampling for PCDD/F control and its } \\
\text { limit of } 0.1 \mathrm{ng}_{\mathrm{TEQ}} / \mathrm{Nm}^{3} \text { was confirmed (it is not } \\
\text { reported in this Table); the one proposed on yearly } \\
\text { basis is an integration of it; the same integration can be } \\
\text { seen with BaP, whilst other parameters did not change } \\
\text { (e.g. CO) }\end{array}$ \\
\hline
\end{tabular}


conventional combustion and must be completed with other parameters set by the regulation (e.g.: CO).

It is an approach that even 10 years ago recognized the limits of the regulation in force but did not focused in detail on the matter of the equivalent impact given by different carcinogenic compounds.

\subsection{Tannery sludge thermochemical treatment case study}

Two big leather-tanning industrial areas are present in Italy. Since long time, the attention was put on the role of Chromium that is used as $\mathrm{Cr}^{\mathrm{III}}$ in the tanning activities, because:

- It can be found in trace in the leather product, causing allergic reactions; that limits also the possibility of the reuse of the material in the frame of a circular economy;

- It is transformed into $\mathrm{Cr}^{\mathrm{VI}}$ if the final treatment of the generated sludge (from wastewater treatment plants) is based on oxidative conditions; that limits the energy recovery from this sludge in spite of the fact that is assimilated to a discarded biomass, thus a renewable source of energy.

In order to find a solution, local and national Authorities promoted a lot of research on the topic in Italy. What emerges to whomever analyzes the problem is an inadequate regulation on emissions to air, as the high content of $\mathrm{Cr}^{\mathrm{III}}$ in sludge could cause high concentrations of $\mathrm{Cr}^{\mathrm{VI}}$ at the stack in case of combustion, with no problems of complying the national regulation on heavy metals emissions. Just to have an example, a concentration of $\mathrm{Cr}^{\mathrm{VI}}$ equal to $100 \mu \mathrm{g} / \mathrm{Nm}^{3}$ and the rest of the heavy metals equal to $400 \mu \mathrm{g} / \mathrm{Nm}^{3}$ results acceptable from the regulation even if the health risk only from $\mathrm{Cr}^{\mathrm{VI}}$ results significantly higher than the risk from PCDD/F assumed equal to the limit $\left(0.1 \mathrm{ng}_{\mathrm{TEQ}} / \mathrm{Nm}^{3}\right)$.

The problem can partially emerge also in the case of gasification, as a local formation of $\mathrm{Cr}^{\mathrm{VI}}$ can be found for local oxidizing conditions even if the global conditions are substoichiometric.

Pyrolysis is worst: the combustion of the produced char offers to $\mathrm{Cr}^{\mathrm{III}}$ there contained the possibility to be oxidized to $\mathrm{Cr}^{\mathrm{VI}}$.

At the end, an important solution is prevention: tanning without $\mathrm{Cr}$ (wet white leather) is more and more introduced in the sector; however, a long time will need to get a full conversion of the approach because of a higher cost compared to the use of $\mathrm{Cr}^{\mathrm{III}}$. Thus, an integration of the regulatory approach is compulsory.

\subsection{Woody waste combustion case study}

In the latest years, EU has started a review of the regulations about the combustion of woody biomass. In Italy virgin wood falls in the category of fuels [13]. Treated wood deriving from wood-furniture industry rejects is considered as waste with consequences on the option of combustion: its combustion is subjected to more stringent restrictions in term of process monitoring and emission limit. A question raised recently in Italy about the possibility to classify slightly treated wood as fuel. A research was developed and analyses before (input) and after pilot combustions (outputs) were made, dealing with organic micropollutants [14] and heavy metals (but not detailing on $\mathrm{Cr}^{\mathrm{VI}}$ ). What is interesting for the present article is the analysis of the heavy metals content in virgin wood. In practice, if wood comes from polluted ground, an anomalous heavy metals amount ( $\mathrm{Cr}$ included) can enter a burner without any control of its emissions. This problem, not yet faced with in Italy, is clear in Germany where some limits are set. In this case, the approach of Germany should become a reference for 
other countries where no control on wood composition is requested. However, the problem remains in case treated wood is burnt as its Cr content usually is not characterized.

\subsection{Special waste gasification case study}

A recent proposal for special waste gasification (followed by immediate combustion of the syngas) has been put forward in the North of Italy [15]. The plant could treat 95,000 t/y of waste with a LHV as $16 \mathrm{MJ} / \mathrm{kg}$. Higher values of LHV are acceptable reducing the feed.

The technology allows material recovery thanks to the integrated vetrification of bottom ash.

Also in this case, the authorization pathway suffers from the aggregation of heavy metals in the limit values to be complied with:

- The sum of $\mathrm{Cd}$ and $\mathrm{Tl}$ has a limit

- The sum of Antimonium, Arsenic, Lead, total Chromium, Cobalt, Manganese, Nickel e Vanadium $(\mathrm{Sb}+\mathrm{As}+\mathrm{Cr}+\mathrm{Pb}+\mathrm{Co}+\mathrm{Cu}+\mathrm{Mn}+\mathrm{Ni}+\mathrm{V})$ has a limit

Being a proposal of plant, it was not possible to know the speciation of metals inside these two categories. In this case study, the speciation was taken from a report of an Italian Region on the monitoring of emissions from modern incinerators [16]. From the average values of the sampling of each metal the fractionation of heavy metals was obtained for the two categories (Table 5). By this way, when facing with dispersion modeling, for each cell of the domain of calculation it was possible to assess the concentrations of specific heavy metals starting from the total concentration of each category.

As the regulation does not set a specific emission limit for $\mathrm{Cr}^{\mathrm{VI}}$, in order to develop the health risk analysis, an assumption of a ratio between $\mathrm{Cr}^{\mathrm{VI}}$ and total $\mathrm{Cr}$ was taken.

As precautionary assumption, data from the Environmental Agency of United Kingdom were taken, based on analyses of flyash separated by the off-gas treatment lines of ten incinerators in that country among 2007 and 2009 [17]. The highest ratio resulted 2.1\%, ratio between $\mathrm{Cr}^{\mathrm{VI}}$ and total $\mathrm{Cr}$. By this way the health risk (cancer risk) can be developed based on the role of $\mathrm{Cr}^{\mathrm{VI}}$. Results demonstrated its comparative relevance against PCDD/Fs [15]. Indeed, low values of dioxin were guaranteed in that proposal thanks to the ability of gasification in inhibiting their formation. Thus, the prevailing carcinogenic driver resulted in

Table 5: Contributions related to each heavy metal on the total of the two categories, whose emissions are regulated.

\begin{tabular}{|c|c|}
\hline Heavy metals & Mass fraction on the total [-] \\
\hline $\mathrm{Cd}$ & 0.907 \\
\hline $\mathrm{Tl}$ & 0.093 \\
\hline $\mathrm{TOTAL}$ & 1.000 \\
\hline $\mathrm{Ni}$ & 0.034 \\
\hline $\mathrm{Mn}$ & 0.058 \\
\hline $\mathrm{Cr}$ total & 0.684 \\
\hline $\mathrm{Pb}$ & 0.075 \\
\hline $\mathrm{Sb}$ & 0.109 \\
\hline $\mathrm{V}$ & 0.034 \\
\hline $\mathrm{As}$ & 0.003 \\
\hline $\mathrm{Co}$ & 0.003 \\
\hline $\mathrm{TOTAL}$ & 1.000 \\
\hline
\end{tabular}


that case $\mathrm{Cr}^{\mathrm{VI}}$ in a context where the national regulation does not take into account this possibility.

In this case study, the renewability of special waste was analyzed in detail showing that the more virtuous case should be the analytic assessment of the biomass-like characteristics of the waste. Flat assumptions on the biogenic characteristics of special waste can be far from the real context, considering that the feed can vary from cellulosic based matter to plastic based matter.

Another interesting aspect of this case study concerns mass valorization of part of the feed: the integration of vitrification is coupled with a partial adjustable recycling of flyash in the vitrification zone, in order to favor the trapping of heavy metals and other inert parts. By this way, flyash will contribute to the generation of a product (the vitrified output). This pathway can be considered a CE oriented downcycling.

Moreover, the off-gas treatment line will adopt a double step of filtration based on the concept of a preliminary filtration subsidiary to a second step where Sodium Bicarbonate is added and flyash is sent to a centralized recycling plant for the regeneration of the additive that can be used back in the plant. This is an option coherent with the principles of CE.

\subsection{SRF and sewage sludge combustion case study}

The sector of SRF (Secondary Refused Fuel) is not exempt from the potential problems from $\mathrm{Cr}^{\mathrm{VI}}$. That is demonstrated by some cases in the sector of cement works authorized for cocombustion of special waste. An interesting example is the one of an Italian cement factory [18] where SRF and thermally dried sewage sludge are authorized for co-combustion. An attention to the problem is demonstrated by the fact that those auxiliary fuels can be accepted at the gate of the plant if they comply with limits of some pollutants including total Chromium and $\mathrm{Cr}^{\mathrm{VI}}$ (Tables 6 and 7).

The use of SRF and sludge is respectively a partial and total substitution of fossil fuel (coal) thus it is an activity of renewable energy exploitation. Moreover, it is related also to circular economy, in the form of downcycling (the valorized mass is included as ash in the final product, the cement). That the whole approach seems to be enhanced. In reality, what lacks in the approach is a control of the situation at the stack, because in that case the control criteria are based only on the verification of a limit as sum of some heavy metals, as usual. Table 8 shows the limits to comply with.

Table 6: Characteristics required for SRF admitted to the cement factory.

\begin{tabular}{|c|c|c|}
\hline Parameters & Limits & Value \\
\hline $\mathrm{LHV}$ & Minimum, as is & $15 \mathrm{MJ} / \mathrm{kg}$ \\
\hline Moisture & Maximum & $25 \%$ \\
\hline $\mathrm{Cl}$ & Referred to dry matter $(\mathrm{DM})$ & $\leq 0.9 \%$ \\
\hline $\mathrm{S}$ & Referred to dry matter & $\leq 0.6 \%$ \\
\hline $\mathrm{Ash}$ & Referred to dry matter & $\leq 20 \%$ \\
\hline $\mathrm{Pb}$ & Volatile, $\mathrm{mg} / \mathrm{kg}$ referred to DM & $\leq 200$ \\
\hline $\mathrm{Cu}$ & Soluble compounds, mg/kg referred to DM & $\leq 300$ \\
\hline $\mathrm{Mn}$ & $\mathrm{mg} / \mathrm{kg}$ referred to DM & $\leq 400$ \\
\hline $\mathrm{Ni}$ & $\mathrm{mg} / \mathrm{kg}$ referred to DM & $\leq 40$ \\
\hline $\mathrm{As}$ & $\mathrm{mg} / \mathrm{kg}$ referred to DM & $\leq 9$ \\
\hline $\mathrm{Cd}+\mathrm{Hg}$ & $\mathrm{mg} / \mathrm{kg}$ referred to DM & $\leq 7$ \\
\hline $\mathrm{Cr}$ & $\mathrm{mg} / \mathrm{kg}$ referred to DM & $\leq 100$ \\
\hline
\end{tabular}


Table 7: Characteristics of thermally dried sewage sludge admitted to the cement factory.

\begin{tabular}{|c|c|c|}
\hline Parameters & Limits & Value \\
\hline LHV & Minimum, as is & $7 \mathrm{MJ} / \mathrm{kg}$ \\
\hline Moisture & Maximum & $15 \%$ \\
\hline $\mathrm{P}$ & Referred to dry matter (DM) & $\leq 3 \%$ \\
\hline $\mathrm{Ash}$ & Referred to DM & $\leq 55 \%$ \\
\hline $\mathrm{Cr}^{\mathrm{VI}}$ & $\mathrm{mg} / \mathrm{kg}$, referred to DM & $\leq 10$ \\
\hline $\mathrm{Cd}+\mathrm{Tl}+\mathrm{Hg}$ & $\mathrm{mg} / \mathrm{kg}$, referred to DM & $\leq 10$ \\
\hline
\end{tabular}

Table 8: Limits for heavy metals at the stack (average daily values).

\begin{tabular}{|c|c|c|}
\hline Parameters & Units & Value (limit) \\
\hline $\mathrm{Hg}$ & $\mathrm{mg} / \mathrm{Nm}^{3}$ & 0.05 \\
\hline$\Sigma \mathrm{Cd}+\mathrm{Tl}$ & $\mathrm{mg} / \mathrm{Nm}^{3}$ & 0.05 \\
\hline$\Sigma \mathrm{Sb}+\mathrm{As}+\mathrm{Cr}+\mathrm{Pb}+\mathrm{Co}+\mathrm{Cu}+\mathrm{Mn}+\mathrm{Ni}+\mathrm{V}$ & $\mathrm{mg} / \mathrm{Nm}^{3}$ & 0.5 \\
\hline
\end{tabular}

\subsection{A proposal for enhanced $\mathrm{Cr}^{\mathrm{VI}}$ control}

What pointed out for $\mathrm{Cr}^{\mathrm{VI}}$ is not limited only to the sector of special waste. Painting activities at industrial level, printing processes and steel making plants can have the same anomalies in the authorization pathway (in Italy and possibly abroad).

For example, painting is assumed often to be a small activity thus a simplification of the authorization is typical of the approach. No Environmental Impact Assessment is necessary in Italy under a threshold of production and a simplified control of the emitted streams is the only request. In the case of [15] it was demonstrated that closing a painting plant to give room to a modern gasifier would allow a reduction of the local impact of $\mathrm{Cr}^{\mathrm{VI}}$ (referring to the authorized values). That because small activities are authorized to emit at low height with a consequent (often not estimated) reduction of the dilution capability of the pollutants released. Thus, the proposal explained below must be considered also in contexts out of the waste sector.

Taking into account what found in the discussed case studies, an enhanced approach to take $\mathrm{Cr}^{\mathrm{VI}}$ impact under control could be the following:

- Ask for total $\mathrm{Cr}$ values at the stack from the laboratories involved in emission characterization (avoiding receiving only sum of multiple heavy metals)

- Set a preliminary threshold for total $\mathrm{Cr}$ (taking into account comparatively the toxicity of the other pollutants emitted and the typical ratio $\mathrm{Cr}^{\mathrm{VI}} /$ total $\mathrm{Cr}$ in the sector) so that, when total $\mathrm{Cr}$ analyses result beyond it:

- $\quad$ specific analyses of $\mathrm{Cr}^{\mathrm{VI}}$ will be performed (case specific) in addition to total $\mathrm{Cr}$ analyses

- $\quad$ a risk analysis will be developed in order verify if a different threshold for total $\mathrm{Cr}$ emissions must be introduced

It is clear that in case the plant is already authorized, the collaboration of the company managing it is compulsory. Moreover, the focus on $\mathrm{Cr}^{\mathrm{VI}}$ shown in this article should be extended to other heavy metals. 
Table 9: CE actions, renewable energy generation aspects and enhanced visions of health impact minimization in the sector of waste to energy (from the case studies).

\begin{tabular}{|c|c|c|}
\hline Type & Description & Priority \\
\hline $\begin{array}{l}\text { Circular } \\
\text { economy }\end{array}$ & $\begin{array}{l}\text { Additive regeneration from } \\
\text { flyash }\end{array}$ & It depends on new plants construction \\
\hline $\begin{array}{l}\text { Circular } \\
\text { economy }\end{array}$ & Flyash integrated vitrification & It depends on new plants construction \\
\hline $\begin{array}{l}\text { Circular } \\
\text { economy }\end{array}$ & Bottom ash vitrification & It depends on new plants construction \\
\hline $\begin{array}{l}\text { Renewable } \\
\text { energy }\end{array}$ & $\begin{array}{l}\text { Avoid flat approaches and } \\
\text { promote detailed analyses of } \\
\text { biogenic content in the waste }\end{array}$ & $\begin{array}{l}\text { It depends on new plants } \\
\text { construction, as the approach can be } \\
\text { changed only for new authorizations }\end{array}$ \\
\hline Health risk & Enhanced $\mathrm{Cr}^{\mathrm{VI}}$ control & Immediate \\
\hline Health risk & $\begin{array}{l}\text { Enhanced approach to set heavy } \\
\text { metals emission limits coherent } \\
\text { with different levels of toxicity }\end{array}$ & $\begin{array}{l}\text { High priority to develop a method } \\
\text { based on the concept of equivalence } \\
\text { toxicity (similarly to the one for } \\
\text { PCDD/F) }\end{array}$ \\
\hline
\end{tabular}

\section{PRIORITIES}

Table 9 resumes the aspects of interest found in the presented case studies concerning CE actions, renewable energy generation and enhanced visions of health impact minimization in the frame of waste to energy.

The case of bottom ash recycling in centralized plants must be cited to complete the vision (this option can be adopted also for existing plants).

As shown in Table 9, a part of the interventions depends on new plants construction. The documents issued by EU on CE seems to expect a strong limitation of new plants. In reality, the present availability of plants for special waste is not homogeneous in Europe and/or is not sufficient. The case of Italy is clear. We see presently an important export of special waste towards other European countries against the principle of proximity in treating waste. In parallel, the growing difficulty for waste export, specifically source separated plastic of low quality, is making critical this situation. The demonstration of this crisis is the anomalous series of recent fire events in Italian companies storing plastics from selective collection.

\section{CONCLUSIONS}

This paper pointed out some criticalities that remain in the sector of emission control and regulation in EU concerning heavy metals. After focusing on the case of $\mathrm{Cr}^{\mathrm{VI}}$, it is clear that the approach, presently adopted according to the regulation in force, does not valorize the scientific knowledge available on the toxicity of heavy metals, exposing the population to potential risks that are not assessed adequately in details.

A proposal to manage the case of $\mathrm{Cr}^{\mathrm{VI}}$ has been put forward in order to integrate the present regulation and avoid not optimized extra-costs.

The criticalities pointed out in this article may be more relevant when the sector of special waste is taken into account: the heavy metals content in the input of a thermo-chemical plant can be more variable than the case of MSW and potentially riskier.

Considering the relevance of the criticality related to heavy metals emission authorization, the Author is working on a novel approach that should take into account the concept of equivalent toxicity of the different heavy metals. 
The modification of the approach in managing heavy metals control is a priority compared to the options analyzed that could be adopted in the waste to energy sector to make it more coherent with $\mathrm{CE}$ and sustainability principles.

\section{REFERENCES}

[1] Ragazzi, M., Tirler, W., Angelucci, G., Zardi, D. \& Rada, E.C., Management of atmospheric pollutants from waste incineration processes: The case of Bozen. Waste Management \& Research, 31(3), pp. 235-240, 2013.

DOI: $10.1177 / 0734242 \times 12472707$.

[2] www.provinz.bz.it/service/resdownload.aspx? source=VIA-UVP\&ID=F01C7619D29 C2838E040007F01003CC6. Accessed on: 24 May 2018.

[3] Rada, E.C., Cioca, L.I. \& Ionescu, G., Energy recovery from municipal solid waste in EU: Proposals to assess the management performance under a circular economy perspective. MATEC Web of Conferences, 121, p. 05006.

[4] Rada, E.C., Ragazzi, M., Torretta, V., Castagna, G., Adami, L. \& Cioca, L.I., Circular economy and waste to energy. AIP Conference Proceedings, 1968, p. 030050, 2018.

[5] Malinauskaite, J. et al., Municipal solid waste management and waste-to-energy in the context of a circular economy and energy recycling in Europe. Energy, 141, pp. 20132044, 2017. DOI: 10.1016/j.energy.2017.11.128.

[6] EU, 2017. Communication from the Commission to the European Parliament, the Council, the European Economic and Social Committee and the Committee of the Regions-The role of waste-to-energy in the circular economy-Brussels, 26.1.2017 $\operatorname{COM}(2017) 34$ final.

[7] http://ec.europa.eu/environment/circular-economy/. Accessed on: 24 May 2018.

[8] http://eur-lex.europa.eu/legal-content/IT/TXT/PDF/?uri=CONSIL:ST_7274_2017

INIT\&qid=1491979061848\&from=IT. Accessed on: 24 May 2018.

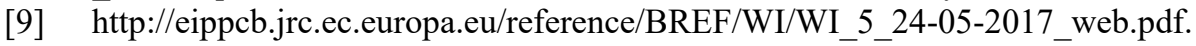
Accessed on: 24 May 2018.

[10] www.gazzettaufficiale.it/eli/id/2016/1/18/16G00006/sg. Accessed on: 24 May 2018 (Law Dec. 28 2015, no.221, "Disposizioni in materia ambientale per promuovere misure di green economy e per il contenimento dell'uso eccessivo di risorse naturali").

[11] Lu, J.W., Zhang, S., Hai, J. \& Lei, M., Status and perspectives of municipal solid waste incineration in China: A comparison with developed regions. Waste Management, 69, pp. 170-186, 2017. DOI: 10.1016/j.wasman.2017.04.014.

[12] www.iarc.fr/. Accessed on: 24 May 2018.

[13] www.comune.trento.it/Aree-tematiche/Ambiente-e-territorio/Rifiuti-urbani. (Studio di Fattibilità - Concessione di lavori per la progettazione, realizzazione e gestione dell'impianto di combustione o altro trattamento termico con recupero energetico per rifiuti urbani e speciali assimilabili in località Ischia Podetti, nel Comune di Trento, Authonomous Province of Trento, June 2009).

[14] Girelli, E., Ragazzi, M., Malloci, E., Rada, E.C. \& Paternoster, L., Agricultural biomass availability for energy conversion in Italy. UPB Scientific Bulletin, Series C, 74(1), pp. 11-18, 2012.

[15] Passamani, G., Rada, E.C., Tirler, W., Tava, M., Torretta, V. \& Ragazzi, M., PCDD/F emissions from virgin and treated wood combustion. International Journal of Energy Production and Management, 2(1), pp. 17-27, 2017. DOI: 10.2495/eq-v2-n1-17-27.

[16] Rada, E.C., Castagna, G., Adami, L., Torretta, V. \& Ragazzi, M., Compensation opportunities and waste-to-energy plants. AIP Conference Proceedings, 1968, p. 030065, 2018. 
[17] www.arpae.it/cms3/documenti/moniter/quaderni/03_emissioni.pdf. Accessed on: 24 May 2018.

[18] www.gov.uk/government/publications/waste-incinerators-guidance-on-impactassessment-for-group-3-metals-stack. Accessed on: 24 May 2018.

[19] www.provincia.como.it/export/sites/provincia-como/temi/territorio/ambiente/ autorizzazione-integrata-ambientale/autorizzazioni/holcim_3ries.pdf. Accessed on: 24 May 2018. 